\title{
Compliance with National Guidelines for the Management of Drug-Drug Interactions in Dutch Community Pharmacies
}

\author{
Henk Buurma, Tom Schalekamp, Antoine CG Egberts, and Peter AGM De Smet
}

A consistent finding in research of health services is the gap between available evidence and clinical practice. It is estimated that $30-40 \%$ of patients do not receive care according to current scientific evidence. ${ }^{1}$ Contrary to medical practice, very little is known about compliance with pharmacy practice guidelines, particularly those concerning the management of drug-drug interaction alerts.

Pharmacists contribute to the detection and prevention of drug therapy-related problems including medication errors, the occurrence of which has been the subject of several studies and part of a public debate about patient safety. ${ }^{2-5}$ The negative impact of one type of drug therapy-related problems, drug-drug interactions, on drug related morbidity has been repeatedly demonstrated. ${ }^{6-8}$

In the Netherlands, 2 guidelines for the management of drug-drug interactions have been developed and are kept up to date by 2 working groups on the basis of published evidence of drug-drug interactions. ${ }^{9}$ This evidence is transformed into alerts with concrete recommendations for their management that are incorporated into community pharmacy software programs for prescription processing. The software program checks new prescriptions for drug-drug interactions using

Author information provided at the end of the text.
BACKGROUND: Pharmacists contribute to the detection and prevention of drug therapy-related problems, including drug-drug interactions. Little is known about compliance with pharmacy practice guidelines for the management of drug-drug interaction alerts.

OBJECTIVE: To measure the compliance of community pharmacists with Dutch guidelines for the management of drug-drug interactions and to determine patient- and prescriber-related determinants for noncompliance.

METHODS: Sixteen clinically relevant drug-drug interactions were included in the study based on certain described criteria. From June to August 2005, Dutch pharmacists $(\mathrm{N}=149)$ collected alerts occurring in daily patient care for these interactions as well as information related to the patient, the alert itself, the prescriber, and the management of the alert. Noncompliance was measured by comparing the management executed by the pharmacy with the national guidelines.

RESULTS: Overall compliance with the guidelines was $69.3 \%(n=423)$, with large differences between the various drug-drug interactions. Male sex (OR 2.25; 95\% Cl 1.52 to 3.31 ), oldest age (>75 y; OR $1.97 ; 95 \% \mathrm{Cl} 1.03$ to 3.75 ), and polypharmacy (>7 medications; OR $2.35 ; 95 \% \mathrm{Cl} 1.46$ to 3.80 ) were associated with a higher probability for noncompliance with the guidelines. Prescriber-related variables had no significant influence on guideline compliance. Substitution of one of the involved agents, recommended for most of the drug-drug interactions, was executed in a small minority of cases. The outcome of interaction management, such as substitution, dose reduction, or temporary stop of one of the agents, was frequently inconsistent with the guidelines. Compliance rates were partly influenced by the ultimate decision made by the prescriber. In that way, pharmacies' compliance was not solely assessed. However, in only $22.5 \%$ of the cases was the drug-drug interaction presented to the prescriber.

CONCLUSIONS: Noncompliance with Dutch guidelines for the management of drug-drug interaction alerts is common in community pharmacies. Further research into underlying reasons for noncompliance is warranted, such as the relation between pharmacist and prescriber in this context.

KEY WORDS: compliance, drug-drug interaction, drug related problem, guideline, intervention, pharmaceutical care, pharmacist, risk management.

Ann Pharmacother 2007;41:2024-31.

Published Online, 30 Oct 2007, www.theannals.com, DOI 10.1345/aph.1K240 
stored information about drugs that will be dispensed simultaneously or have already been dispensed to the patient. The objective of our study was to determine the compliance rate of community pharmacists to national guidelines for the management of drug-drug interaction alerts as well as patient- and prescriber-related determinants for noncompliance.

\section{Methods}

\section{SETTING AND STUDY POPULATION}

All Dutch community pharmacies using the Pharmacom information technology system $(\mathrm{N}=791)$ were invited (once, via mail) to participate in this study, of which $172(21.7 \%)$ responded positively. Ultimately, several pharmacies decided not to participate due to heavy workload, and 149 (18.8\%)—serving approximately 1.4 million patients, which is almost 9\% of the Dutch population-were included in this study. During a 3 month period (June-August 2005) each participating pharmacy was requested to collect alerts of drug-drug interactions selected for this study (see below) as encountered during routine daily patient care. The participating pharmacies received a pretested study protocol and the coordinating research center was available for questions throughout the study. The work was conducted in compliance with the requirements of the institutional review board of the Department of Pharmacoepidemiology and Pharmacotherapy, Utrecht University.

\section{SELECTION OF THE DRUG-DRUG INTERACTIONS INCLUDED}

The Pharmacom information technology system monitors approximately 300 different types of drug-drug interactions. ${ }^{10}$ For our study we selected interactions that fulfilled the following criteria: the available evidence had to be classified as 3 or higher, and the clinical relevance had to be classified as $\mathrm{C}$ or higher, according to the classification system developed and maintained by a working group of the Scientific Institute of Dutch Pharmacists (WINAp) that has been described in detail elsewhere. ${ }^{9}$ In brief, within that classification system, drug-drug interactions are classified on a 6 point relevance scale ranging from not serious to very life-threatening (category A-F, respectively) and on a 5 point evidence scale ranging from not proven to very well proven (category $0-4$, respectively). In other words, all the included drug-drug interactions had to have potentially harmful consequences. An additional criterion was that the management of these drug-drug interaction alerts according to the national guidelines had to involve the substitution of one of the interacting drugs, which was sometimes presented as the only option and sometimes accompanied by an alternative option. This led to the inclusion of 16 drug-drug interactions (Table 1). An important feature of the selected drug-drug interactions is the rela- tively low frequency of recurrent alerts, because of the nature of one of the interacting agents (eg, antibiotics, antimycotics, phosphodiesterase type 5 [PDE-5] inhibitors). This decreased the chance that the drug-drug interaction had already been managed in the past for the same patient.

\section{COLLECTION AND CLASSIFICATION OF DATA}

A computer program was developed enabling each pharmacy to extract and collect the selected drug-drug interaction alerts that had occurred during the previous week. These data extractions were subsequently sent by the pharmacist to the coordinating research center electronically. On the first day of the week the pharmacist was requested to execute the data extraction and to send the data to the research center. On the third, fourth, and fifth day this procedure was repeated. For each drug-drug interaction alert sent to the research center, a questionnaire was returned to the community pharmacy by email. Subsequently, completed questionnaires were sent to the research center by email, postal mail, or fax.

On the questionnaire form, pharmacists, who had not all been necessarily involved with the drug-drug interaction alert, recorded information related to the patient (age, sex, estimated current drug use), the alert itself (medicines involved, same or different prescribers for the interacting drugs, type of prescriber of latest prescription [ie, general practitioner or specialist]), and information about the management of that drug-drug interaction alert by the pharmacy. Management was categorized as external action or no external action. External action was defined as an intervention directed at the prescriber, advice given to the patient, or other, such as communication with the anticoagulation clinic. The specific external action or its outcome had to be specified. Some examples of specific action taken or their outcome include the substitution of one of the interacting medicines, a dose change of one of the interacting medicines, or advice to obtain plasma concentrations (eg, potassium) related to drugs.

In case internal pharmacy procedures did not require external action, the respondent was asked to give reasons for that (eg, recurrent alert or alert already managed in the past).

\section{COMPLIANCE WITH GUIDELINES}

Table 1 summarizes the management guidelines for the selected drug-drug interactions presented to pharmacists on the computer screen each time that the drug-drug interaction alert occurs, as well as in a yearly updated textbook. ${ }^{10} \mathrm{~A}$ working group of Health Base Foundation, a knowledge center closely connected to the Pharmacom information technology system, is responsible for the content of this textbook, which provides background information about several drug therapy-related problems, such as drug-drug 
interactions and drug-disease interactions. Moreover, algorithmic strategies for management are provided, which were used as the gold standard for the evaluation of the management of drug-drug interactions by pharmacists. The comparison between the management output as described on the questionnaires and the guideline was made by one of the authors (HB) and checked by another (TS). The outcome of this comparison was threefold: compliant, noncompliant, or uncertainty as to assessment. Finally, the association between noncompliance with the guidelines and several patient-related characteristics (ie, sex, age, number of drugs in use) and prescriber-related characteris- tics (different prescribers for the interacting drugs, prescriptions prescribed during different consultations, latest prescription from other prescriber [ie, not general practitioner]) was examined.

\section{DATA ANALYSIS}

Data were analyzed using standard descriptive data analysis (SPSS version 12.0, SPSS Inc., Chicago, IL). Logistic regression analysis was used to estimate the strength of the association between characteristics and noncompliance with the guideline.

\begin{tabular}{|c|c|c|}
\hline Interaction & Possible Consequences & Proposed Management \\
\hline Statins-macrolides & myopathy, rhabdomyolysis & $\begin{array}{l}\text { macrolide only for } 1 \text { day: pt. instructed to contact physician immediately in case of } \\
\text { severe myopathy; in other cases: stop or reduce dose of simvastatin or atorvastatin } \\
\text { during macrolide course (maximum } 20 \mathrm{mg} \text { and } 40 \mathrm{mg} \text {, respectively); no known } \\
\text { problems with fluvastatin, pravastatin, or rosuvastatin; when maintaining use of } \\
\text { low-dose statin: pt. instruction given as above }\end{array}$ \\
\hline Statins-antimycotics & myopathy, rhabdomyolysis & $\begin{array}{l}\text { at start of statin: postpone use of statin until end of antimycotic course or choose } \\
\text { pravastatin or rosuvastatin; at start of fluconazole } \leq 200 \mathrm{mg} / \text { day: no action; at start } \\
\text { of fluconazole }>200 \mathrm{mg} / \text { day or other antimycotic: substitute another antimycotic } \\
\text { (eg, terbinafine), temporarily stop statin, or change to pravastatin or rosuvastatin }\end{array}$ \\
\hline Coumarins-TMP/SMX & bleeding & substitution for TMP/SMX or warning to anticoagulation clinic via fax ${ }^{a}$ \\
\hline Digoxin-macrolides & digoxin toxicity & $\begin{array}{l}\text { substitution for macrolide (with high serum digoxin level as risk factor, daily dose } \\
\geq 0.25 \mathrm{mg} \text { ) }\end{array}$ \\
\hline PDE-5 inhibitors-nitrates & $\begin{array}{l}\text { drop in systolic and diastolic } \\
\text { blood pressure }\end{array}$ & $\begin{array}{l}\text { substitution for PDE- } 5 \text { inhibitor; in case of maintenance treatment with nitrate: } \\
\text { substitution with } \beta \text {-blocker }\end{array}$ \\
\hline Theophylline-macrolides & theophylline toxicity & $\begin{array}{l}\text { at start of macrolide: substitution for macrolide or monitor theophylline serum level }{ }^{\text {b }} \text {; at } \\
\text { start of theophylline: begin with low dose, later dose increase guided by serum } \\
\text { concentration }\end{array}$ \\
\hline Coumarins-antimycotics & bleeding & $\begin{array}{l}\text { fluconazole ( } 1 \text { day course): no intervention; other regimens of azole antimycotics: } \\
\text { substitution (particularly miconazole, fluconazole, or voriconazole) or warning to } \\
\text { anticoagulation clinic via fax }\end{array}$ \\
\hline TCAs-terbinafine & TCA toxicity & $\begin{array}{l}\text { at start of TCA: low dose of TCA to maximum of } 50 \mathrm{mg} \text { daily; older pts.: } 25 \mathrm{mg} \text { daily; at } \\
\text { start of terbinafine: substitution for terbinafine or dose reduction of TCA to maximum } \\
\text { of } 50 \mathrm{mg} \text { daily; older pts.: } 25 \mathrm{mg} \text { daily (starting dose regimens and dose reductions } \\
\text { of TCA preferably guided by serum concentration control) }\end{array}$ \\
\hline Theophylline-quinolones & theophylline toxicity & $\begin{array}{l}\text { substitution for quinolone (not by macrolide) or dose decrease of theophylline to } 50 \% \\
\text { in case of ciprofloxacin or pipemidic acid }\end{array}$ \\
\hline $\begin{array}{l}\text { Phenytoin-TMP/SMX } \\
\text { or trimethoprim or } \\
\text { sulfonamides }\end{array}$ & phenytoin toxicity & $\begin{array}{l}\text { at start of TMP/SMX or trimethoprim or sulfonamides: substitution by another antibiotic } \\
\text { (no fluoroquinolone); at start of phenytoin: begin with low dose, later dose increase } \\
\text { guided by serum concentration/clinical effect }\end{array}$ \\
\hline $\begin{array}{l}\text { Methotrexate- TMP/SMX } \\
\text { or trimethoprim }\end{array}$ & bone marrow suppression & substitution for TMP/SMX or trimethoprim (no safe time interval is known) \\
\hline Digoxin-itraconazole & digoxin toxicity & $\begin{array}{l}\text { substitution for itraconazole or dose decrease of digoxin, guided by serum } \\
\text { concentration }\end{array}$ \\
\hline $\begin{array}{l}\text { PDE-5 inhibitors-CYP3A4 } \\
\text { inhibitors }\end{array}$ & sildenafil or vardenafil toxicity & $\begin{array}{l}\text { sildenafil-ritonavir: avoidance of sildenafil or dose reduction to maximum of } 25 \mathrm{mg} \\
\text { over } 48 \mathrm{~h} \text {; sildenafil-other CYP3A4 inhibitors: dose reduction of sildenafil to } \\
\text { maximum of } 25 \mathrm{mg} \text { over } 48 \mathrm{~h} \text {; vardenafil-indinavir or very strong CYP3A4 inhibitors: } \\
\text { avoidance of vardenafil or substitution of CYP3A4 inhibitor; vardenafil-other } \\
\text { CYP3A4 inhibitors: dose reduction of vardenafil to maximum of } 5 \mathrm{mg} \text { over } 24 \mathrm{~h}\end{array}$ \\
\hline Carbamazepine-macrolides & carbamazepine toxicity & substitution for CYP3A4 inhibiting macrolide (ie, erythromycin, clarithromycin) \\
\hline $\begin{array}{l}\text { Terfenadine-QT interval } \\
\text { prolonging drugs }\end{array}$ & $\begin{array}{l}\text { QT interval prolongation } \\
\text { ventricular arrhythmias }\end{array}$ & substitution for terfenadine by other antihistaminic agent \\
\hline St. John's wort-digoxin & digoxin toxicity & avoidance of combination \\
\hline
\end{tabular}




\section{Results}

Of the 858 returned questionnaires, all cases concerning unjustified alerts $(\mathrm{n}=97$; mostly because the first drug had already been stopped) and all alerts missing essential information $(\mathrm{n}=17)$ were excluded from the analysis. The remaining 744 drug-drug interaction alerts were collected by 149 pharmacies, with a range of 1-17 alerts per pharmacy (average 5). The alerts involved an approximately equal number of males $(n=309)$ and females $(n=301)$. The mean \pm SD age was $64.5 \pm 14.7$ years (range $2-99$ ). The number of drugs used at the time of the alert was $6.4 \pm 3.3$ (range $0-22$ ), excluding dermatologic preparations. The frequency of alerts for the 16 included drug-drug interactions (Table 2) was variable, ranging from 205 alerts for statin-macrolide interaction to 1 alert for a St John's wort-digoxin interaction. One-hundred thirty-four cases (18.0\%) could not be evaluated because they contained, primarily, a recurrent alert with no information about its management.

Of all alerts for which an assessment was possible $(\mathrm{n}=$ 610), pharmacists undertook external action in $79.5 \%(\mathrm{n}=$ 485; Figure 1). In case of external action, the prescriber was consulted in $28.2 \%(\mathrm{n}=137)$, advice was given to the patient in $72.8 \%$, and another action was undertaken in $14.4 \%$, mainly information giving to the anticoagulation clinic. Twofold actions occurred several times.

Overall compliance with the guideline was $69.3 \%(\mathrm{n}=$ 423 ) with highly variable rates depending on the type of interaction. A high compliance rate was found for interactions involving coumarin anticoagulants $(92.5 \%$ and 95.8\%). Compliance was also relatively high for tricyclic antidepressants-terbinafine (90.9\%), statins-macrolides
(89.8\%), statins-antimycotics (82.2\%), and PDE-5 inhibitors-CYP3A4 inhibitors (75.0\%). A relatively low compliance rate was found for interactions involving theophylline (45.0\% and 21.6\%), digoxin-macrolides (8.9\%), and PDE-5 inhibitors-nitrates (2.8\%).

The degree of compliance also varied with management recommendations. For alerts for which substitution was the only proposed management option, we found low compliance $(9.2 \%)$ with the guideline (digoxin-macrolides, methotrexate/trimethoprim/sulfamethoxazole or trimethoprim, carbamazepine-macrolides, terfenadine-QT interval prolonging agents, St. John's wort-digoxin). For alerts for which a clear alternative option was possible in addition to substitution, the compliance amounted to $82.2 \%$ (statinsmacrolides, statins-antimycotics, coumarins-trimethoprim/ sulfamethoxazole, theophylline-macrolides, coumarins-antimycotics, tricyclic antidepressants- terbinafine, theophylline-quinolones, digoxin-itraconazole).

A temporary stop of one of the agents was executed in 30 cases $(4.9 \%), 19(63.3 \%)$ of which were consistent with the guidelines. Dose adjustment was performed in 17 cases (2.8\%), of which about half ( 8 cases) were in accordance with the guidelines.

The association between patient- and prescriber-related variables and noncompliance with the guidelines is presented in Table 3. Adjusted for all other variables, male sex (OR 2.25; 95\% CI 1.52 to 3.31), the highest age category ( $>75 \mathrm{y}$; OR $1.97 ; 95 \%$ CI 1.03 to 3.75), and current use of more than 7 medications (OR 2.35; 95\% CI 1.46 to 3.80 ) indicate a higher probability for noncompliance concerning the whole group of selected drug-drug interactions. Prescriberrelated variables, such as different prescribers for both drugs,

\begin{tabular}{|lccc|}
\hline \multicolumn{1}{|c|}{ Table 2. Compliance with the Guidelines for Management of 16 Drug-Drug Interactions } \\
\hline \multicolumn{1}{|c|}{ Interaction } & Pts., $\mathbf{n}$ & $\begin{array}{c}\text { Uncertainty as } \\
\text { to Assessment, } \\
\mathbf{n}(\%)\end{array}$ & $\begin{array}{c}\text { Compliance } \\
\text { after } \\
\text { Adjustment, }{ }^{\text {a }} \%\end{array}$ \\
\hline Statins-macrolides & 205 & $8(3.9)$ & $89.8(177 / 197)$ \\
Statins-antimycotics & 119 & $12(10.1)$ & $82.2(88 / 107)$ \\
Coumarins-TMP/SMX & 90 & $18(20.0)$ & $95.8(69 / 72)$ \\
Digoxin-macrolides & 75 & $19(25.3)$ & $8.9(5 / 56)$ \\
PDE-5 inhibitors-nitrates & 62 & $26(41.9)$ & $2.8(1 / 36)$ \\
Theophylline-macrolides & 53 & $16(30.1)$ & $21.6(8 / 37)$ \\
Coumarins-antimycotics & 49 & $9(18.3)$ & $92.5(37 / 40)$ \\
Tricyclic antidepressants-terbinafine & 34 & $12(35.3)$ & $90.9(20 / 22)$ \\
Theophylline-quinolones & 24 & $4(16.7)$ & $45.0(9 / 20)$ \\
Phenytoin-TMP/SMX or trimethoprim or sulfonamides & 10 & $4(40.0)$ & $50.0(3 / 6)$ \\
Methotrexate-TMP/SMX or trimethoprim & 7 & $4(57.1)$ & $33.3(1 / 3)$ \\
Digoxin-itraconazole & 5 & $1(20.0)$ & $50.0(2 / 4)$ \\
PDE-5 inhibitors-CYP3A4 inhibitors & 5 & $1(20.0)$ & $75.0(3 / 4)$ \\
Carbamazepine-macrolides & 3 & $0(0.0)$ & $0(0 / 3)$ \\
Terfenadine-QT interval prolonging drugs & 2 & $0(0.0)$ & $0(0 / 2)$ \\
St. John's wort-digoxin & 1 & $0(0.0)$ & $0(0 / 1)$ \\
TOTAL & 744 & $134(18.0)$ & $69.3(423 / 610)$ \\
\hline PDE-5 $=$ phosphodiesterase type 5; TMP/SMX = trimethoprim/sulfamethoxazole. & & & \\
\hline aMinus cases with uncertainty as to assessment. & & & \\
\hline
\end{tabular}


were not shown to have significant influence on the noncompliant management of drug-drug interaction alerts.

\section{Discussion}

To our knowledge, this is the first multicenter study evaluating compliance with national guidelines concerning the management of drug-drug interaction alerts in com- munity pharmacies. The overall compliance rate amounted to $69.3 \%$. The degree of compliance varied with the nature of the drug-drug interaction, patient characteristics, and the nature of the recommended management actions in the guidelines.

The degree of and variation in noncompliance with clinical guidelines in our study matches the outcomes of studies concerning medical practitioners' compliance with di-

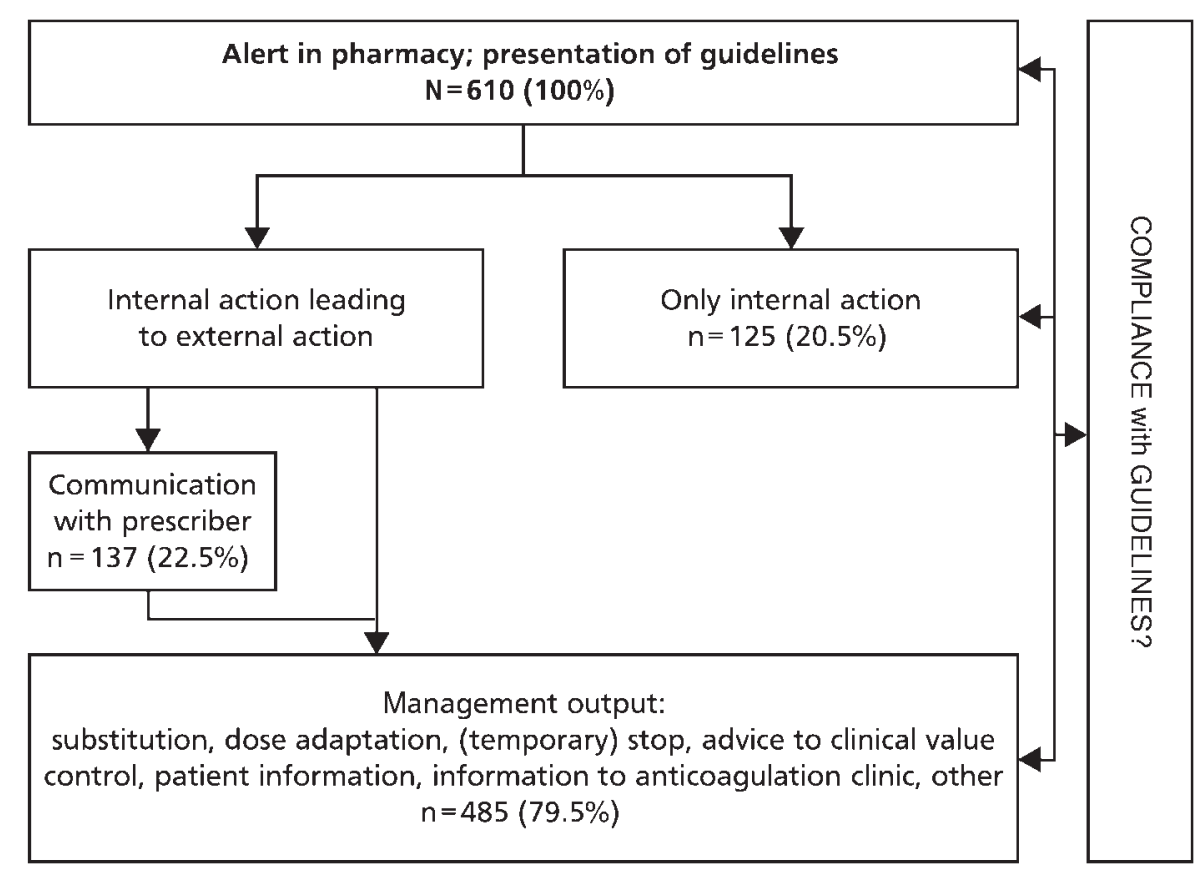

Figure 1. Alert management in Dutch community pharmacies of 16 potentially harmful drug-drug interactions.

\begin{tabular}{|c|c|c|c|c|}
\hline \multirow[b]{3}{*}{ Characteristic } & \multicolumn{2}{|c|}{ 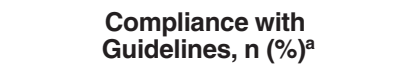 } & \multirow{2}{*}{\multicolumn{2}{|c|}{ OR $(95 \% \mathrm{Cl})$}} \\
\hline & \multirow{2}{*}{$\begin{array}{l}\text { Noncompliant } \\
n=187\end{array}$} & \multirow{2}{*}{$\begin{array}{c}\text { Compliant } \\
n=423\end{array}$} & & \\
\hline & & & Crude & Adjusted $^{\mathrm{b}}$ \\
\hline \multicolumn{5}{|l|}{ Patient-related } \\
\hline Sex, male & $117(62.6)$ & $192(45.4)$ & 2.05 (1.44 to 2.93$)$ & 2.25 (1.52 to 3.31$)$ \\
\hline \multicolumn{5}{|l|}{ Age, y } \\
\hline $0-50$ & $22(11.8)$ & $73(17.3)$ & (reference) & 1 (reference) \\
\hline $51-65$ & $55(29.4)$ & $136(32.2)$ & 1.34 (0.76 to 2.37$)$ & $1.25(0.67$ to 2.34$)$ \\
\hline $66-75$ & $53(28.3)$ & $127(30.0)$ & 1.39 (0.78 to 2.46$)$ & $1.24(0.66$ to 2.33$)$ \\
\hline$>75$ & $56(29.9)$ & $85(20.1)$ & 2.19 (1.22 to 3.92$)$ & $1.97(1.03$ to 3.75$)$ \\
\hline \multicolumn{5}{|l|}{ Drugs in use, $\mathrm{n}$} \\
\hline $0-4$ & $43(23.0)$ & $151(35.7)$ & (reference) & 1 (reference) \\
\hline $5-7$ & $59(31.6)$ & $137(32.4)$ & $1.51(0.96$ to 2.39$)$ & $1.51(0.93$ to 2.45$)$ \\
\hline$>7$ & $80(42.8)$ & $124(29.3)$ & 2.27 (1.46 to 3.52$)$ & 2.35 (1.46 to 3.80$)$ \\
\hline \multicolumn{5}{|l|}{ Prescriber-related } \\
\hline Different prescribers for interacting drugs & $59(31.6)$ & $136(32.2)$ & $1.01(0.69$ to 1.46$)$ & $1.00(0.62$ to 1.61$)$ \\
\hline Prescriptions during different consultations & $166(88.8)$ & $383(90.5)$ & $0.81(0.46$ to 1.41$)$ & $0.78(0.42$ to 1.45$)$ \\
\hline $\begin{array}{l}\text { Latest prescription from other prescriber (mostly } \\
\text { specialist), not general practitioner }\end{array}$ & $43(23.0)$ & $106(25.1)$ & 0.90 (0.60 to 1.35$)$ & $0.77(0.46$ to 1.30$)$ \\
\hline
\end{tabular}


agnostic or therapeutic guidelines. ${ }^{1,11,12}$ However, it is questionable whether this issue concerning pharmacists' compliance can be fully compared with the outcomes of other professionals. An important difference in our study on drug-drug interactions is that pharmacists must sometimes present the problem with some management options to the prescriber, who ultimately decides on the management of the drug-drug interaction. In our study, pharmacists directly discussed the problem with the prescriber in $22.5 \%$ of the cases $(n=137)$; the compliance rate of these cases was lower $(56.2 \% ; \mathrm{n}=77)$ than the average compliance rate in the study $(69.3 \% ; \mathrm{n}=423)$.

There were considerable differences in the quality of the compliant as well as the noncompliant management of pharmacists, which we describe to some extent and illustrate by using examples from this study. Compliant management can imply a rigorous intervention, meaning, for instance, contact with the prescriber as well as communication with the patient and with a substitution of one of the interacting drugs as an outcome. However, compliant management can also imply no action, for example, in case of a 1 day course of fluconazole (interaction: coumarins-antimycotics). The same applies to noncompliant interventions. We found superfluous interventions, such as a warning to the anticoagulation clinic in case of a 1 day course of fluconazole combined with a coumarin anticoagulant. However, we also found interventions that could be considered potentially doubtful or even potentially negative concerning patient outcomes. Examples were a temporary stop of digoxin use and a temporary stop of theophylline use. Finally, it must be emphasized that some noncompliant outcomes of interventions made by pharmacists, which were mostly in concordance with the prescriber, were certainly realistic: low dosage of digoxin with relatively young age, rise of serum concentration assessed as not problematic because the physician was just about to increase the dosage (carbamazepine), substitution of terbinafine tablet by terbinafine creme.

There are several possible reasons for guideline noncompliance. We cannot exclude that the relation with the prescriber might have affected the intervention. Substitution of one of the interacting drugs was executed in a limited number of cases, even when substitution was the only proposed intervention. Perhaps many pharmacists find substitution of one of the interacting drugs a difficult and timeconsuming type of management, because it requires intervention toward the prescribing physician. In other studies, interprofessional barriers have been identified concerning the relationship between community pharmacists and physicians. ${ }^{13}$ In a majority of cases, more easily applicable management options were preferred, such as a warning to the anticoagulation clinic, temporary stop of a statin, or dose reduction of one of the medicines, mostly without interference of the prescriber. Nevertheless, a Dutch study revealed that pharmacists and general practitioners largely agree on the surveillance role that a pharmacist should fulfill. ${ }^{14}$ In addition, we observed that in several instances the prescriber ultimately decided not to change one of the prescribed medicines as recommended. It is an intriguing question whether this is associated with the decision frequently made by physicians to override drug-drug interaction alerts ${ }^{15}$ and/or with a lack of professional persuasiveness of the pharmacist. Continued scientific inquiry is needed regarding pharmacists' and physicians' attitudes and behavior and the quality of their communication regarding drug-drug interaction guidelines and management.

Patient characteristics may contribute to noncompliance as well, but our finding of a higher probability of noncompliance for some patient variables, such as male sex, older age, and polypharmacy, is hard to explain. We would have expected more vigilance concerning this drug therapy-related problem in elderly patients with complex pharmacotherapy and being at higher risk. Concerning polypharmacy, a similar finding has been reported by Halkin et al. ${ }^{16}$ in a study about preventing drug interactions. The paradox between what was expected and what was found regarding the relationship between intervention and risk factor needs further exploration. A similar paradox has been described elsewhere as the treatment-risk paradox concerning the relative undertreatment with lipid-lowering therapy of high-risk elderly patients. ${ }^{17}$ In another study, concerning the relative undertreatment of heart failure patients at highest risk, it has been described as the risk-treatment mismatch. ${ }^{18}$

\section{LIMITATIONS OF THE STUDY}

First, the participating pharmacies constituted a voluntary sample, which may have resulted in a positive selection bias concerning the performance of pharmacies. The participating pharmacies all used the Pharmacom operating system, which is used by about $45 \%$ of Dutch pharmacies. The guidelines for this system are produced by the Health Base Foundation, which was described in the Methods section. The other Dutch pharmacies use other software programs, but all use the guideline system produced and maintained by another working group not described in this article. Therefore, there is the problem concerning a potential issue of reduced external validity concerning all Dutch pharmacies, but we have no information suggesting a lower or higher quality of pharmacies using the Pharmacom system. Secondly, it may be possible that some drug-drug interaction alerts were not selected or reported. Pharmacists were free to extract data every week, send them to the research center, and finally fill in and return the questionnaires. The burden of a high workload as a consequence of participation in this research project and/or in the pharmacy and the holiday season in the Netherlands resulted in a varied participation of pharma- 
cies (range 1-17 drug-drug interaction alerts per pharmacy). In other words, some pharmacies may have affected the results more than others. A certain-to our opinion, low-degree of recall bias should not be ignored. It is well known that Dutch pharmacies document the management of a drug-drug interaction and other alerts, for instance, on prescription papers. Pharmacies using the Pharmacom system have an electronic documentation system in which the management of a drug-drug interaction can be described as well. Repeated testing could have influenced pharmacy management of drug-drug interactions. The frequency of most of the included drug-drug interactions, however, is low; only for some was a considerable number found. However, the average number of returned questionnaires was 5 per pharmacy (range 1-17). In combination with a study period of 3 months, we consider this issue to be a minor limitation. A certain degree of underreporting is also possible, because over-the-counter drugs, such as St John's wort, are seldom recorded in Dutch pharmacies and thus will not contribute to drug-drug interaction alerts. Nevertheless, this drug-drug interaction was included since all criteria were fulfilled. However, there is a low risk of not detecting drug-drug interactions because of a low degree of fragmented prescription filling in the Netherlands. ${ }^{19}$ Dutch patients are in general loyal to one pharmacy, leading to rather complete medication records. Another limitation is the fact that the compliance rates are partly influenced by the ultimate decision made by the prescriber. In that way, pharmacies' compliance was not solely assessed. However, as described above, in only $22.5 \%$ of the cases was the drug-drug interaction problem presented to the prescriber. Finally, in this cohort a relatively low occurrence was found for several drug-drug interactions, meaning that the estimation of compliance rates for these drug-drug interactions is less accurate.

\section{Conclusions}

Overall compliance with Dutch guidelines for the management of drug-drug interactions was about $70 \%$, with large differences between the various drug-drug interactions. Male sex, oldest age, and polypharmacy ( $>7$ medications) were associated with a higher probability for noncompliance. Some prescriber-related variables had no significant influence on guideline compliance. Substitution of one of the involved agents, recommended for most of the drug-drug interactions, was executed in a minority of cases. The outcome of interaction management, such as substitution, dose reduction, or temporary stop of one of the agents, was frequently inconsistent with the guideline. Compliance rates were partly influenced by the ultimate decision made by the prescriber. In that way, pharmacies' compliance was not solely assessed. However, in only $22.5 \%$ of the cases was the drug-drug interaction problem presented to the pre- scriber. Further research into underlying reasons for noncompliance is warranted, such as the relationship between pharmacist and prescriber in this context.

Henk Buurma PharmD PhD, Director, SIR Institute for Pharmacy Practice and Policy, Leiden, Netherlands; Researcher, Department of Pharmacoepidemiology and Pharmacotherapy, Utrecht Institute for Pharmaceutical Sciences, Utrecht University, Utrecht, Netherlands

Tom Schalekamp PharmD PhD, Researcher, Department of Pharmacoepidemiology and Pharmacotherapy, Utrecht Institute for Pharmaceutical Sciences, Utrecht University

Antoine CG Egberts PharmD PhD, Professor, Department of Pharmacoepidemiology and Pharmacotherapy, Utrecht Institute for Pharmaceutical Sciences, Utrecht University; Hospital Pharmacist, Hospital Pharmacy 'Midden-Brabant,' TweeSteden Hospital and St Elisabeth Hospital, Tilburg, Netherlands

Peter AGM De Smet PharmD PhD, Researcher, Scientific Institute of Dutch Pharmacists, The Hague, Netherlands; Professor, Department of Clinical Pharmacy, University Medical Centre St Radboud, Nijmegen, Netherlands

Reprints: Dr. Buurma, Department of Pharmacoepidemiology and Pharmacotherapy, Utrecht Institute for Pharmaceutical Sciences, Utrecht University, PO Box 80.082, 3508 TB Utrecht, Netherlands, fax +3130 2539166, h.buurma@stevenshof.nl

Funding from the PRISMA (Practice Research In Co-operation With Pharmacists) foundation was used to assist in the preparation of this study.

We thank all pharmacists who participated in the study. Special thanks to Rohini van Exel, pharmacy student, for her support in collecting the data and some preliminary research. Special thanks to PharmaPartners company, especially Eric Hiddink PharmD and Martijn Nieuwhof, for their support to start this study and for developing a special computer program, enabling each pharmacy to extract and collect the selected drug-drug interactions. Thanks also to Martine Kruijtbosch MSc for her help in developing the database.

\section{References}

1. Grol R, Grimshaw J. From best evidence to best practice: effective implementation of change in patients' care. Lancet 2003;362:1225-30.

2. Sandars J, Esmail A. The frequency and nature of medical error in primary care: understanding the diversity across studies. Fam Pract 2003; 20:231-6.

3. Kohn LT, Corrigan JM, Donaldson MS, eds. To err is human. Building a safer health system. Washington, DC: National Academy Press, 1999.

4. Singhal PK, Raisch DW, Gupchup GV. The impact of pharmaceutical services in community and ambulatory care settings: evidence and recommendations for future research. Ann Pharmacother 1999;33:1336-55. DOI 10.1345/aph.18440

5. Buurma H, De Smet PA, Leufkens HG, Egberts AC. Evaluation of the clinical value of pharmacists' modifications of prescription errors. Br J Clin Pharmacol 2004;58:503-11.

6. Jankel CA, Fitterman LK. Epidemiology of drug-drug interactions as a cause of hospital admissions. Drug Saf 1993;9:51-9.

7. Bouvy ML, Heerdink ER, Hoes AW, Leufkens HG. Effects of NSAIDs on the incidence of hospitalisations for renal dysfunction in users of ACE inhibitors. Drug Saf 2003;26:983-9.

8. Juurlink DN, Mamdani M, Kopp A, Laupacis A, Redelmeier DA. Drug-drug interactions among elderly patients hospitalized for drug toxicity. JAMA 2003;289:1652-8.

9. Van Roon EN, Flikweert S, le Comte M, et al. Clinical relevance of drug-drug interactions: a structured assessment procedure. Drug Saf 2005;28:1131-9.

10. Commentaren Medicatiebewaking 2004-2005 [Commentaries medication surveillance]. Houten, Netherlands: Health Base, 2004.

11. Opstelten W, van Essen GA, Moons KG, et al. Do herpes zoster patients receive antivirals? A Dutch national survey in general practice. Fam Pract 2005;22:523-8. 
12. Van Duijn HJ, Kuyvenhoven MM, Schellevis FG, Verheij TJ. Determinants of prescribing of second-choice antibiotics for upper and lower respiratory tract episodes in Dutch general practice. J Antimicrob Chemother 2005;56:420-2.

13. Hughes CM, McCann S. Perceived interprofessional barriers between community pharmacists and general practitioners: a qualitative assessment. Br J Gen Pract 2003;53:600-6.

14. Muijrers PE, Knottnerus JA, Sijbrandij J, Janknegt R, Grol RP. Changing relationships: attitudes and opinions of general practitioners and pharmacists regarding the role of the community pharmacist. Pharm World Sci 2003;25:235-41.

15. Weingart SN, Toth M, Sands DZ, Aronson MD, Davis RB, Phillips RS. Physicians' decisions to override computerized drug alerts in primary care. Arch Intern Med 2003;163:2625-31.

16. Halkin H, Katzir I, Kurman I, Jan J, Malkin BB. Preventing drug interactions by online prescription screening in community pharmacies and medical practices. Clin Pharmacol Ther 2001;69:260-5.

17. Ko DT, Mamdani M, Alter DA. Lipid-lowering therapy with statins in high-risk elderly patients: the treatment-risk paradox. JAMA 2004;291: 1864-70.

18. Lee DS, Tu JV, Juurlink DN, et al. Risk-treatment mismatch in the pharmacotherapy of heart failure. JAMA 2005;294:1240-7.

19. Klungel OH, de Boer A, Paes AH, Herings RM, Seidell JC, Bakker A. Agreement between self-reported antihypertensive drug use and pharmacy records in a population-based study in the Netherlands. Pharm World Sci 1999;21:217-20.

Obediencia a las Recomendaciones Nacionales para Gestionar las Interacciones Farmacológicas en las Farmacias Comunitarias Holandesas

H Buurma, T Schalekamp, ACG Egberts, y PAGM De Smet

Ann Pharmacother 2007;41:2024-31.

\section{EXTRACTO}

ANTECEDENTES: Los farmacéuticos contribuyen a la detección y prevención de problemas relacionados con los medicamentos, como las interacciones farmacológicas (IF). No existe mucha información sobre la obediencia a las recomendaciones para gestionar las alertas de IF.

OBJETrvos: Cuantificar la obediencia de las farmacias comunitarias a las recomendaciones holandesas para gestionar las IF y determinar los factores relacionados con el paciente y con el facultativo que conllevan a la desobediencia.

MÉTODOs: En el estudio se incluyeron 16 IF clínicamente relevantes seleccionadas según ciertos criterios descritos. Desde junio-agosto de 2005, farmacias holandesas $(n=149)$ recopilaron las alertas observadas en la atención diaria al paciente dirigida especialmente a estas interacciones, junto con la información relacionada con el paciente, con la propia alerta, con el facultativo, y la gestión de la alerta. Para cuantificar la desobediencia, se comparó la gestión llevada a cabo por la farmacia con la dictada por las recomendaciones nacionales.

RESULTADOS: La obediencia global a las recomendaciones fue del 69.3\% $(n=423)$ con grandes diferencias entre las distintas IF. El sexo masculino, (OR 2.25; IC de 95\% 1.52 y 3.31), la mayor edad (>75 años) (OR 1.97; IC de 95\% 1.03 y 3.75), y la politerapia (>7 medicaciones) (OR 2.35; IC de $95 \% 1.46$ y 3.80) se asociaron con mayor probabilidad de desobediencia a las recomendaciones. Las variables relacionadas con el facultativo no mostraron ninguna influencia significativa sobre esta obediencia. Sólo en la menor parte de los casos se llevó a cabo la sustitución de uno de los fármacos implicados, medida recomendada para la mayoría de las IF. Frecuentemente, el desenlace de la gestión de la interacción, como la sustitución de un medicamento, la reducción de la dosis o la interrupción temporal de uno de los medicamentos, no coincidía con las recomendaciones. Las tasas de obediencia estaban determinadas en parte por la decisión final que tomaba el facultativo. En este sentido, la obediencia de las farmacias no se valoró en solitario. No obstante, sólo se presentó el problema de IF al facultativo en el 22.5\% de los casos.

CONCLUSIONES: La desobediencia a las recomendaciones holandesas es común en las farmacias comunitarias. Se deben estudiar con mayor profundidad las razones subyacentes de esta desobediencia, como la relación entre el farmacéutico y el facultativo en este contexto.

Traducido por Violeta Lopez Sanchez

Conformité des Pharmaciens aux Lignes Directrices sur les Interactions Médicamenteuses

H Buurma, T Schalekamp, ACG Egberts, et PAGM De Smet

Ann Pharmacother 2007;41:2024-31.

RÉSUMÉ

MISE EN CONTEXTE: Les pharmaciens contribuent à la détection et à la prévention des problèmes reliés aux médicaments incluant les interactions médicamenteuses (IM). Il y a peu d'évidence sur le respect par les pharmaciens des lignes directrices portant sur la gestion des IM. OBJECTIFS: Mesurer le respect par les pharmaciens communautaires en Hollande de lignes directrices sur la gestion des IM et déterminer les facteurs reliés aux patients et aux prescripteurs pouvant influencer le non-respect des lignes directrices.

MÉTHODES: Seize IM cliniquement significatives ont été incluses dans une étude réalisée selon certains critères. De juin-août 2005, les pharmaciens ont émis des alertes signalant la présence de ces interactions et donnant de l'information aux patients et prescripteurs sur la conduite à prendre. La conformité a été mesurée en comparant les actions prises aux lignes directrices.

RÉSULTATS: Dans l'ensemble, les règles ont été respectées dans 69,3\% des cas $(\mathrm{n}=423)$. Les patients de sexe masculin (rapport de cotes [RC]: 2.25; IC 95\% 1.52 à 3.31), d'âge plus élevé (>75 ans) (RC 1.97; IC 95\% 1.03 à 3.75), et avec une polypharmacie (>7 médicaments) (RC 2.35; IC 95\% 1.46 à 3.80) ont été associés à risque plus élevé de nonconformité aux règles. Les variables reliés au prescripteur n'ont pas démontré d'influence sur les résultats. La substitution d'un des médicaments impliqués, recommandée dans la plupart des IM, n'a été exécutée que dans une minorité des cas. Les gestes posés tels que la substitution, la réduction de la dose, l'arrêt temporaire d'un des médicaments étaient fréquemment non en conformité avec les lignes directrices. Le taux de conformité était influencé par la décision ultime du prescripteur, ce qui a affecté le taux de conformité en pharmacie. Cependant, seulement $22.5 \%$ des cas d'IM ont été présentés au prescripteur.

CONCLUSIONS: La nonconformité aux lignes directrices portant sur les IM est courante dans les pharmacies communautaires en Hollande. D'autres études sont nécessaires afin de comprendre les causes sous-jacentes, notamment la relation entre le prescripteur et le pharmacien dans ce contexte précis.

Traduit par Nicolas Paquette-Lamontagne 